ORIGINAL ARTICLE

\title{
Biomonitoring results and cytogenetic markers among harbour workers with potential exposure to river silt aerosols
}

\author{
R Wegner, K Radon, R Heinrich-Ramm, B Seemann, A Riess, F Koops, B Poschadel, D Szadkowski
}

Occup Environ Med 2004;61:247-253. doi: 10.1136/oem.2003.007146

See end of article for authors' affiliations ....................

Correspondence to: Dr med R Wegner, Zentralinstitut für Arbeitsmedizin der Freien und Hansestadt Hamburg, Seewartenstr. 10, D-20459 Hamburg, Germany; Ralf.Wegner@ bug.hamburg.de

Accepted 17 June 2003
Background: Workers on dredgers and lighters on rivers are potentially exposed to a variety of substances.

Aims: To determine the internal load of heavy metals and arsenic as well as levels of cytogenetic markers in workers exposed to river silt aerosols.

Methods: One hundred exposed workers were examined up to eight times within three years. Additionally, 100 control workers were studied once. Blood samples were analysed for lead, mercury, and cadmium. Additionally, micronuclei frequency and sister chromatid exchange (SCE) rates were determined. Urinary samples were analysed for cadmium, mercury, nickel, chromium, and arsenic. Information on potential confounders, such as smoking habits and consumption of fish were assessed.

Results: Apart from some increased concentrations of mercury in blood (maximum $14.6 \mu \mathrm{g} / \mathrm{l}$ ) and arsenic in urine (maximum $356.5 \mu \mathrm{g} / \mathrm{l}$ ) all measurements were within reference values. None of the exposure and effect markers were found to be significantly increased in exposed workers compared to non-exposed controls. In multiple linear regression models, mercury levels in blood as well as the concentration of arsenic in urine were strongly related to fish consumption. Cadmium levels in blood as well as urinary cadmium concentrations were strongly related to smoking habits. After adjusting for smoking habits, SCE rates were associated with cadmium levels in blood.

Conclusion: Increased exposure levels or enhanced levels of cytogenetic markers were not found in workers exposed to river silt aerosols. However, cadmium exposure in blood was related to SCE frequency.
1 $\mathrm{n}$ order to maintain a sufficient depth for shipping traffic in harbours it is necessary to dredge the rivers. ${ }^{1}$ For example, in the harbour of Hamburg 2.5 million $\mathrm{m}^{3}$ of mud are dredged annually. Organic and inorganic pollutants of the river water are mainly bound to the silt fraction of the mud. This fraction represents about one half of the total mud. About $20 \%$ of the silt particles are $<20 \mu \mathrm{m}$ in diameter.

While dredging the river, workers are exposed to these aerosols and dusts mainly via inhalation. In particular, seamen on suction dredgers working in aerosol fumes of the silt may inhale these particles (fig 1). However, another route of exposure is dermal absorption as well as ingestion. The latter is mainly caused by the fact that workers are living on the dredgers and lighters and are therefore taking their meals in the work environment.

The river silt may contain high levels of heavy metals and arsenic. $^{2}{ }^{3}$ Reference measurements in the river silt of the River Elbe performed in a local laboratory indicated high concentrations of lead, cadmium, mercury, chromium, nickel, and arsenic (median/maximum levels of 235/530, 4/16, 7/23, 240/570, 95/215, 38/90 mg/kg oven dry mass, respectively).

Therefore, the aim of this study was to measure the internal load of heavy metals and arsenic in seamen working on dredgers and lighters in the harbour of Hamburg. Additionally, the association between markers of biomonitoring and cytogenetic markers should be assessed. A longitudinal design was chosen to answer these questions because exposure may vary, largely due to frequent changes of dredging locations, seasonal variations, and non-occupational background exposures (for example, nutrition). Office workers in the harbour of Hamburg served as controls.

\section{METHODS \\ Subjects \\ Harbour workers}

In a meeting organised by the employers and the investigators, all 399 seamen with potential exposure to river silt aerosols (mean age (SD) 46.7 (10.9) years, mean duration of employment $13.6(9.2)$ years) were informed about the aims of the survey and invited to take part in the study. Of 161 $(40 \%)$ volunteers (mean age (SD) 44.8 (11.0) years, mean duration of employment 13.0 (9.3) years) a sample of 100 was chosen for the study (mean age (SD) 45.3 (10.7) years, mean duration of employment 13.7 (9.1) years). In order to include a sufficient number of subjects with potentially higher exposure levels, all workers on suction dredgers were included $(\mathrm{n}=30)$. The remaining 70 subjects were selected at random.

\section{Controls}

One hundred male office workers working in the administration office of the harbour agreed to participate in the study (mean age (SD) 46.3 (10.4) years).

\section{Design}

Harbour workers

Up to eight measurements were performed over a three year period (1994-97). Seventy eight subjects took part in all eight measurements. The reasons for drop-out were retirement

Abbreviations: BEI, biological exposure indices; ETS, environmental tobacco smoke; SCE, sister chromatid exchange 


\section{Main messages}

- Harbour workers did not show increased levels of heavy metals, arsenic, frequency of micronuclei, or SCE rates compared to controls.

- Cadmium levels in blood were associated with smoking status and SCE rates.

- Fish consumption was a predictor of arsenic concentrations in urinary and mercury levels in blood samples.

$(n=5)$, sick leave on the day of the study $(n=5)$, and active refusal $(n=12)$.

At each survey, a medical examination and a standardised interview with special focus on nutrition and smoking habits were performed. Additionally, whole blood samples as well as a urinary samples were taken on-site at the end of the working day. The following parameters were determined:

- Blood:

- Lead

- Cadmium

- Mercury

- Frequency of micronuclei

- Sister chromatid exchange rate (SCE rate).

- Urine:

- Cadmium

- Chromium

- Nickel

- Arsenic

- Mercury (7th and 8th examination only).

\section{Controls}

Office workers were studied once during the last year of the survey in parallel with the seamen. Each day, six harbour workers and six age matched controls were studied alternately to take circadian rhythm as well as seasonal patterns into account (matched examinations). Calliper matching was used for age using a three year interval.

\section{Biomonitoring}

Following the Standard Operating Procedures of the German Research Council (Deutsche Forschungsgemeinschaft), ${ }^{4}$ atomic absorption spectrometry was used to determine metals and metalloids in blood and urine (AAS 4000 and Z3030 by Perkin Elmer, SPE 800 by Varian). Lead in blood was measured directly with palladium modifier. To determine cadmium in blood, samples were deproteinised using nitric acids. Chelatisation and extraction was used to condition urinary samples for cadmium and nickel analysis. To determine the toxicologically relevant amount of arsenic in urine (inorganic arsenic species and their mono- and dimethylated metabolites), direct hydride generation was used. Blood and urinary samples were prepared for mercury analysis using cold vapour technique/amalgamation. Precision control was carried out with commercial urine (Lyphocheck, Bio-Rad, Munich, Germany) or spiked animal blood. Relative standard deviations between series ranged from $2.6 \%$ to $13.0 \%(\mathrm{n}=17-24)$.

Detection limits for lead, cadmium, and mercury in blood were $10.0,0.4$, and $0.6 \mu \mathrm{g} / \mathrm{l}$, respectively; the lower limit of detection for cadmium, mercury, chromium, nickel, and

\section{Policy implications}

- The association between environmental tobacco smoke exposure and cadmium levels in blood should be further assessed.

- The potential health effects of arsenic exposure due to chronic fish consumption should be evaluated.

arsenic in urine was $0.2,0.6,0.6,0.2$, and $1.5 \mu \mathrm{g} / \mathrm{l}$, respectively.

In order to exclude differences in the concentration of urine of harbour workers and controls, creatinine was determined in all urinary samples during the matched examinations using an enzymatic assay (Creatinine PAP, Fa. Boehringer, Mannheim; Photometer PCP 6121, Fa. Eppendorf, Hamburg, Germany).

\section{Cytogenetic markers}

A modified cytokinesis block method was used to determine the lymphocyte micronuclei frequency. ${ }^{5}$ In short, lymphocytes were cultured for 72 hours, and cytochalasin B was added after 44 hours of incubation. After washing, fixing, and harvesting the cells on to slides, they were dried and stained with 4',6-diamino-2-phenylindole (DAPI, $5 \mathrm{mg} / \mathrm{l}$; Serva, Heidelberg, Germany). Two thousand binucleated cells per sample were scored blindly by the same reader.

Sister chromatid exchange (SCE) rates were assessed as described previously. ${ }^{78}$ Whole blood cultures were established in chromosome medium containing 5-bromo-2-deoxyuridine for 72 hours. Colcemid $(0.1 \mu \mathrm{g} / \mathrm{ml})$ was added to each culture two hours before the end of incubation. Lymphocytes were washed, harvested on to slides, and air dried chromosome preparations were made. Slides were stained with Giemsa and scored blindly by the same reader. Fifteen well differentiated diploid second division metaphases with at least 40 chromosomes were scored in each subject.

\section{Statistical analyses}

Because of the non-normal distribution of the exposure and effect levels, descriptive statistics are presented as quartiles with ranges. Values below the detection limits were entered as half of the detection limit.

Comparisons between exposed subjects and controls were based on the matched measurements. Bivariate associations between potential risk factors and levels of exposure and cytogenetic markers were analysed using the Mann-Whitney $\mathrm{U}$ test. Seasonal trends over the course of the survey were tested using MANOVA. Multivariate analyses were done

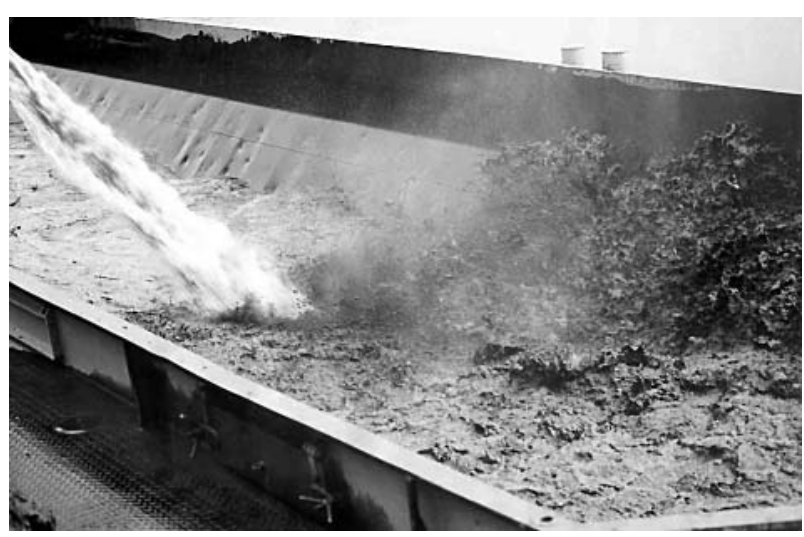

Figure 1 Aerosol fumes on a suction dredger. 
using multiple linear regression models. In these models, all variables bivariately associated with exposure or effect levels were included. The model assumptions for linear regression models have been tested graphically using residual plots.

For statistical analyses the Statistica (Tulsa, USA) and SPSS (USA) software packages have been used.

\section{RESULTS}

\section{Descriptives}

Exposed subjects were more likely to smoke than controls (41\% $\vee 29 \%$ active smokers, respectively). Fifty per cent of both groups reported that they eat fish at least once a week.

The results of the physical examinations among the exposed subjects did not indicate any job specific diseases.

\section{Biomonitoring results}

\section{Harbour workers}

Table l shows the biomonitoring results of the harbour workers over the course of the survey. Eighty two per cent of the urinary chromium concentrations were below detection limit; therefore, these results were not further analysed. Apart from cadmium in blood $(26 \%$ of the measurements below the detection limit) less than $11 \%$ of the biomonitoring results were below the detection limit.

One level of mercury in blood was higher than the current biological exposure indices (BEI, $15 \mu \mathrm{g} / \mathrm{l}$ ). All other concentrations of heavy metals in blood and urinary samples were below these limits.

In contrast, 70 urinary samples $(9.4 \%)$ had arsenic levels above the current BEI $(35 \mu \mathrm{g} / \mathrm{l})$. The maximum level of arsenic in urine $(356 \mu \mathrm{g} / \mathrm{l})$ was found during the first examination. However, no trend in arsenic levels was seen over the course of the survey. The same was true for all exposure parameters under study besides lead concentrations in blood. These levels decreased over the course of the survey $\left(p_{\text {Friedman }}<0.001\right)$. No seasonal trends were seen.

\section{Potential risk factors and levels of exposure}

Table 2 shows the results of bivariate analyses. Within the group of harbour workers, only cadmium levels in urine were slightly higher in workers on suction dredgers compared to other harbour workers $(\mathrm{p}<0.05)$. Duration of employment was not associated with exposure levels during the matched surveys.

Comparing harbour workers and controls, harbour workers had significantly higher levels of cadmium in blood and urine. In contrast, lead levels in blood and nickel concentrations in urinary samples were significantly lower among harbour workers. The latter associations have been confirmed in the multivariate models. However, only $8 \%$ of the variance could be explained by these models (table 3 ).

Age was associated with higher biomonitoring results for almost all parameters under study. These associations were

Table 1 Biomonitoring results and cytogenetic markers for harbour workers over the course of the study

\begin{tabular}{|c|c|c|c|c|c|c|c|c|c|}
\hline & \multicolumn{8}{|c|}{ No. of examination } & \multirow[b]{2}{*}{ BEl* $^{*}$} \\
\hline & 1 & 2 & 3 & 4 & 5 & 6 & 7 & 8 & \\
\hline $\mathrm{n}$ & 100 & 98 & 95 & 95 & 95 & 94 & 83 & 82 & \\
\hline \multicolumn{10}{|l|}{$\begin{array}{l}\text { Blood } \\
\text { Lead ( } \mu \mathrm{g} / \mathrm{l})\end{array}$} \\
\hline Median & 61.0 & 54.1 & 48.6 & 58.6 & 47.2 & 49.8 & 45.9 & 41.0 & \multirow{3}{*}{300} \\
\hline $25 / 75$ & $45.0 / 74.5$ & $39.6 / 71.1$ & $36.6 / 65.8$ & $45.7 / 73.2$ & $33.4 / 61.0$ & $37.7 / 67.0$ & $33.9 / 64.7$ & $28.9 / 52.9$ & \\
\hline $\operatorname{Min} / \max$ & $7.5 / 118.1$ & $10.6 / 179.1$ & $5.0 / 136.6$ & $12.9 / 174.1$ & $5.0 / 95.4$ & $15.2 / 116.0$ & $5.0 / 172.8$ & $5.0 / 111.8$ & \\
\hline \multicolumn{10}{|c|}{ 然 } \\
\hline Median & 0.65 & 0.80 & 0.50 & 0.80 & 0.60 & 0.50 & 0.80 & 0.60 & \multirow[t]{3}{*}{5} \\
\hline $25 / 75$ & $0.2 / 1.3$ & $0.4 / 1.3$ & $0.2 / 1.2$ & $0.4 / 1.3$ & $0.4 / 1.2$ & $0.2 / 1.0$ & $0.4 / 1.6$ & $0.2 / 1.3$ & \\
\hline $\operatorname{Min} / \max$ & $0.2 / 3.8$ & $0.2 / 3.4$ & $0.2 / 3.4$ & $0.2 / 3.4$ & $0.2 / 3.0$ & $0.2 / 3.0$ & $0.2 / 3.4$ & $0.2 / 3.1$ & \\
\hline \multicolumn{10}{|c|}{ Mercury ( $\mu \mathrm{g} / \mathrm{l})$} \\
\hline Median & 1.45 & 2.00 & 1.80 & 1.80 & 1.90 & 2.00 & 1.90 & 1.60 & \multirow[t]{3}{*}{15} \\
\hline $25 / 75$ & $0.6 / 2.3$ & $1.2 / 3.0$ & $0.9 / 3.1$ & $1.1 / 3.4$ & $1.3 / 2.9$ & $1.3 / 2.7$ & $1.4 / 3.4$ & $0.9 / 2.7$ & \\
\hline $\operatorname{Min} / \max$ & $0.3 / 13.7$ & $0.3 / 12.8$ & $0.3 / 14.6$ & $0.3 / 12.9$ & $0.3 / 16.3$ & $0.3 / 13.2$ & $0.3 / 11.8$ & $0.3 / 9.6$ & \\
\hline \multicolumn{10}{|c|}{ Micronuclei frequency (/500 cells) } \\
\hline Median & 6.97 & 8.24 & 8.01 & 6.16 & 4.73 & 5.47 & 6.17 & 7.44 & \multirow[t]{3}{*}{-} \\
\hline $25 / 75$ & $5.3 / 9.7$ & $5.9 / 10.1$ & $6.5 / 9.9$ & $4.8 / 8.5$ & $3.5 / 6.3$ & $4.4 / 7.7$ & $4.7 / 8.2$ & $5.0 / 10.4$ & \\
\hline $\operatorname{Min} / \max$ & $1.7 / 16.0$ & $2.0 / 17.3$ & $2.6 / 18.0$ & $2.0 / 14.9$ & $1.0 / 12.6$ & $1.8 / 16.1$ & $2.2 / 19.0$ & $1.5 / 19.9$ & \\
\hline \multicolumn{10}{|c|}{ SCE rate (/cell) } \\
\hline Median & 9.48 & 10.2 & 10.6 & 10.1 & 10.7 & 10.5 & 10.7 & 10.6 & \multirow[t]{3}{*}{-} \\
\hline $25 / 75$ & $8.5 / 10.5$ & $9.2 / 11.2$ & $9.4 / 11.8$ & $9.2 / 11.3$ & $9.8 / 11.9$ & $9.6 / 11.9$ & $9.5 / 12.3$ & $9.5 / 12.1$ & \\
\hline $\operatorname{Min} / \max$ & $4.8 / 14.6$ & $7.4 / 15.5$ & $8.0 / 15.3$ & $7.0 / 15.7$ & $6.6 / 15.9$ & $7.6 / 17.6$ & $6.8 / 15.6$ & $6.6 / 14.5$ & \\
\hline \multicolumn{10}{|c|}{ Urine } \\
\hline \multicolumn{10}{|c|}{ Cadmium ( $\mu \mathrm{g} / \mathrm{l}$ ) } \\
\hline Median & 0.70 & 0.85 & 0.60 & 0.70 & 0.70 & 0.70 & 0.50 & 0.70 & \multirow{3}{*}{$\begin{array}{l}{[5 \mu \mathrm{g} / \mathrm{g}} \\
\text { creatinine] }\end{array}$} \\
\hline $25 / 75$ & $0.4 / 1.4$ & $0.4 / 1.2$ & $0.3 / 1.2$ & $0.4 / 1.3$ & $0.4 / 1.3$ & $0.4 / 1.2$ & $0.3 / 0.9$ & $0.3 / 1.2$ & \\
\hline $\operatorname{Min} / \max$ & $0.1 / 4.2$ & $0.1 / 4.3$ & $0.1 / 3.2$ & $0.1 / 3.3$ & $0.1 / 3.6$ & $0.1 / 2.6$ & $0.1 / 3.6$ & $0.1 / 3.3$ & \\
\hline \multicolumn{10}{|l|}{ Nickel ( $\mu \mathrm{g} / \mathrm{l})$} \\
\hline Median & 1.10 & 0.90 & 1.00 & 1.00 & 1.00 & 0.60 & 1.00 & 0.90 & \multirow[t]{3}{*}{-} \\
\hline $25 / 75$ & $0.7 / 1.8$ & $0.4 / 1.5$ & $0.6 / 1.5$ & $0.7 / 1.5$ & $0.6 / 1.3$ & $0.4 / 1.0$ & $0.6 / 1.7$ & $0.5 / 1.5$ & \\
\hline $\operatorname{Min} / \max$ & $0.1 / 8.1$ & $0.1 / 5.7$ & $0.1 / 4.3$ & $0.1 / 11.9$ & $0.1 / 4.7$ & $0.1 / 4.4$ & $0.2 / 6.9$ & $0.1 / 4.8$ & \\
\hline \multicolumn{10}{|c|}{ Chromium ( $\mu \mathrm{g} / \mathrm{l})$} \\
\hline Median & 0.3 & 0.3 & 0.3 & 0.3 & 0.3 & 0.3 & - & - & \multirow[t]{3}{*}{25} \\
\hline $25 / 75$ & $0.3 / 0.3$ & $0.3 / 0.3$ & $0.3 / 0.3$ & $0.3 / 0.7$ & $0.3 / 0.3$ & $0.3 / 0.6$ & - & - & \\
\hline Min/max & $0.3 / 2.0$ & $0.3 / 1.4$ & $0.3 / 3.4$ & $0.3 / 4.1$ & $0.3 / 2.6$ & $0.3 / 1.8$ & - & - & \\
\hline \multicolumn{10}{|l|}{ Arsenic ( $\mu \mathrm{g} / \mathrm{l})$} \\
\hline Median & 9.30 & 8.60 & 8.40 & 7.70 & 7.20 & 8.40 & 7.80 & 8.20 & \multirow[t]{3}{*}{35} \\
\hline $25 / 75$ & $6.3 / 16.7$ & $5.2 / 14.9$ & $5.5 / 15.1$ & $5.2 / 18.8$ & $4.8 / 15.6$ & $5.4 / 12.9$ & $4.5 / 14$ & $5.2 / 15.4$ & \\
\hline $\operatorname{Min} / \max$ & $0.8 / 356.5$ & $1.9 / 208.1$ & $2.1 / 203.8$ & $1.7 / 137.5$ & $1.7 / 232.9$ & $0.8 / 64.8$ & $0.8 / 105.6$ & $0.8 / 134.1$ & \\
\hline
\end{tabular}




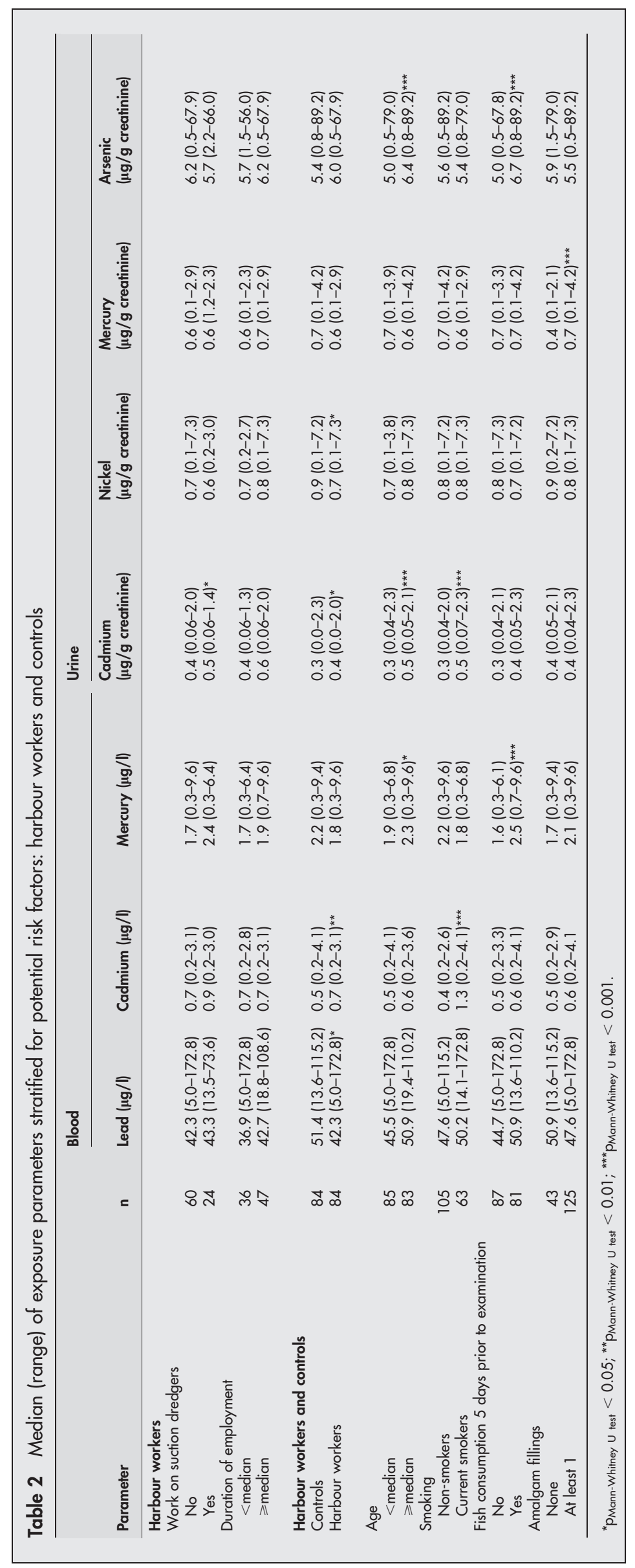

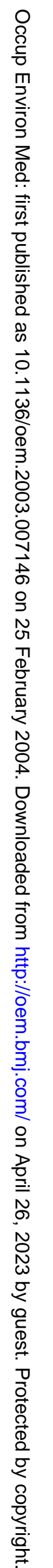


Table 3 Multiple regression analysis of metals, arsenic, frequency of micronuclei, and SCE rate as dependent variables and exposure, age, smoking status, and fish consumption 5 days prior to the study as predictors

\begin{tabular}{|c|c|c|c|c|c|c|}
\hline & \multicolumn{3}{|l|}{ Blood $(\mu \mathrm{g} / \mathrm{l})$} & \multicolumn{3}{|c|}{ Urine $(\mu \mathrm{g} / \mathrm{g}$ creatinine) } \\
\hline & $\beta$ & SE of $\beta$ & $t$ & $\beta$ & SE of $\beta$ & $t$ \\
\hline Cadmium & $\left(n=168 ; R^{2} 0.39\right)$ & & & $\left(n=168 ; R^{2} 0.15\right)$ & & \\
\hline Harbour workers $v$ controls & 0.058 & 0.10 & 0.56 & 0.075 & 0.064 & 1.18 \\
\hline Age (years) & 0.0002 & 0.005 & 0.04 & 0.011 & 0.003 & $3.75^{\star \star \star}$ \\
\hline Current smoker (yes vs. no) & 1.06 & 0.106 & $9.97^{* \star *}$ & 0.202 & 0.065 & $3.10^{* *}$ \\
\hline Fish consumption (yes vs. no) & 0.131 & 0.105 & 1.25 & 0.080 & 0.065 & 1.23 \\
\hline Mercury & $\left(n=168 ; R^{2} 0.16\right)$ & & & $\left(n=168 ; R^{2} 0.08\right)$ & & \\
\hline Harbour workers $v$ controls & 0.071 & 0.248 & 0.29 & -0.088 & 0.11 & -0.83 \\
\hline Age (years) & 0.027 & 0.012 & $2.26^{*}$ & -0.004 & 0.005 & -0.76 \\
\hline Current smoker (yes $v$ no) & -0.17 & 0.254 & -0.66 & -0.13 & 0.11 & -1.23 \\
\hline Fish consumption (yes $v$ no) & 1.062 & 0.251 & $4.23^{* * *}$ & 0.025 & 0.11 & 0.23 \\
\hline Amalgam fillings $(>0 \vee 0)$ & 0.16 & 0.28 & 0.58 & 0.366 & 0.12 & $3.04^{* *}$ \\
\hline Lead & $\left(n=168 ; R^{2} 0.08\right)$ & & & & & \\
\hline Harbour workers $v$ controls & -8.03 & 3.64 & $-2.21^{*}$ & & & \\
\hline Age (years) & 0.34 & 0.17 & 1.95 & & & \\
\hline Current smoker (yes $v$ no) & 7.86 & 3.73 & $2.11^{*}$ & & & \\
\hline Fish consumption (yes $v$ no) & 2.47 & 3.69 & 0.67 & & & \\
\hline Nickel & & & & $\left(n=168 ; R^{2} 0.05\right)$ & & \\
\hline Harbour workers $v$ controls & & & & -0.39 & 0.17 & $-2.30^{*}$ \\
\hline Age (years) & & & & 0.013 & 0.008 & 1.67 \\
\hline Current smoker (yes v no) & & & & -0.090 & 0.17 & -0.52 \\
\hline Fish consumption (yes $v$ no) & & & & -0.014 & 0.17 & -0.08 \\
\hline Arsenic & & & & $\left(n=168 ; R^{2} 0.11\right)$ & & \\
\hline Harbour workers $v$ controls & & & & 0.24 & 1.99 & 0.12 \\
\hline Age (years) & & & & 0.27 & 0.09 & $2.83^{* *}$ \\
\hline Current smoker (yes $v$ no) & & & & 2.45 & 2.04 & 1.20 \\
\hline Fish consumption (yes $v$ no) & & & & 5.32 & 2.02 & $2.64^{\star *}$ \\
\hline
\end{tabular}

significant for mercury concentrations in blood as well as cadmium and arsenic levels in urinary sample and were robust for adjustment in the multivariate models.

Current smoking was a strong predictor for cadmium levels in blood and urine in the bivariate as well as in the multivariate models. In contrast, fish consumption in the five days prior to the examination was strongly associated with mercury levels in blood and arsenic levels in urine. These associations were confirmed in the multivariate models. Including ex-smoking as predictor in the multivariate models did not change the results (data not shown). Additionally, log transformation of the dependent parameters did not change the conclusions.

\section{Cytogenetic markers}

Micronuclei frequencies as well as SCE rates over the course of the survey are given in table 1. No seasonal trend was seen nor did the results change systematically over the three years under study.

Comparing the matched examinations of harbour workers and controls (table 4), controls had significantly higher micronuclei frequencies than harbour workers. The major predictor of micronuclei frequencies was age. The latter result was confirmed in the multivariate regression analysis (table 5). In this model the association between exposure status and micronuclei frequency was no longer significant.

SCE rates were bivariately associated with cadmium levels in blood and urine. Additionally, smokers had non-significantly higher SCE rates than non-smokers. In the multiple linear regression model, current smoking and cadmium levels in blood were independent predictors of SCE rates.

\section{DISCUSSION}

Repeated measurements in a large number of harbour workers did not indicate increased biomonitoring levels of heavy metals. In contrast, urinary arsenic concentrations were above recent exposure limits in a large number of subjects. Besides age, the major predictor of these enhanced exposure levels was fish consumption. Likewise, the major predictors for heavy metal concentrations in biomonitoring and cytogenetic markers were non-occupational factors such as smoking habits.

Selection bias cannot be ruled out in our survey as only $40 \%$ of the harbour workers volunteered to participate in the survey. However, it seems unlikely that this bias was differential for the exposure under study. Eighty two of the 100 harbour workers stayed under study until the end of the survey. Therefore, selection bias over the course of the study could be minimised. While drop-outs were mainly due to retirement or loss of interest in the study, some participants were lost to follow up due to long term health reasons. It cannot be ruled out that these health complaints were due to occupation. Using matched surveys with alternating examinations of six harbour workers and six controls on the same day climatic factors, seasonal variations, and circadian rhythm were taken into account. This study was done in order to generate hypotheses rather than to test specific hypotheses. Therefore, multiple statistical testing has been done and should be considered in interpretation of borderline significant results.

Our results indicate high levels of arsenic in urine of some exposed workers. These levels were not different from controls and were mainly associated with recent fish consumption. Fish and mussels are known to contain arsenic. ${ }^{9}$ In our study, many of the participants reported regular consumption of salted young herring. We have recently shown that the consumption of salted young herring is associated with levels of arsenic in urine $>100 \mu \mathrm{g} / \mathrm{l}^{10} \mathrm{In}$ general, subjects daily consuming fish have a mean daily intake of arsenic of $1.38 \mu \mathrm{g} / \mathrm{kg}$ body weight while those who 
Table 4 Median (range) of cytogenetic markers stratified for potential risk factors: harbour workers and controls

\begin{tabular}{|c|c|c|c|}
\hline Median (range) & $\mathbf{n}$ & Micronuclei frequency & SCE rate \\
\hline \multicolumn{4}{|l|}{ Harbour workers } \\
\hline \multicolumn{4}{|l|}{ Work on suction dredgers } \\
\hline No & 58 & $5.9(2.2-19.0)$ & $10.7(7.6-15.6)$ \\
\hline Yes & 24 & $5.7(2.5-14.9)$ & $10.0(6.6-13.7)$ \\
\hline \multicolumn{4}{|l|}{ Duration of employment } \\
\hline$<$ median ( 14 years) & 35 & $5.8(2.2-12.7)$ & $10.1(7.1-14.0)$ \\
\hline$\geqslant$ median (14 years) & 46 & $5.7(2.5-19.0)$ & $10.9(6.6-15.6)$ \\
\hline \multicolumn{4}{|c|}{ Harbour workers and controls } \\
\hline Controls & 83 & $7.1(2.7-13.4)$ & $10.2(7.7-14.5)$ \\
\hline Harbour workers & 82 & $5.8(2.2-19.0)^{*}$ & $10.5(6.6-15.6)$ \\
\hline \multicolumn{4}{|l|}{ Age } \\
\hline$<$ median (48 years) & 83 & $5.8(2.2-12.7)$ & $10.2(7.1-15.6)$ \\
\hline$\geqslant$ median ( 48 years) & 82 & $7.3(3.1-19.0)^{\star \star}$ & $10.4(6.6-14.5)$ \\
\hline \multicolumn{4}{|l|}{ Smoking } \\
\hline Non-smokers & 102 & $6.6(2.2-14.9)$ & $9.7(6.6-14.1)$ \\
\hline Current smokers & 63 & $6.2(2.5-19.0)$ & $11.7(8.7-15.6)$ \\
\hline \multicolumn{4}{|c|}{ Fish consumption 5 days prior to examination } \\
\hline No & 84 & $6.1(2.5-14.9)$ & $10.1(6.6-15.6)$ \\
\hline Yes & 81 & $6.7(2.2-19.0)$ & $10.4(7.6-14.5)$ \\
\hline \multicolumn{4}{|l|}{ Amalgam fillings } \\
\hline None & 42 & $6.7(2.7-19.0)$ & $10.0(7.8-14.5)$ \\
\hline At least 1 & 123 & $6.4(2.2-13.4)$ & $10.4(6.6-15.6)$ \\
\hline \multicolumn{4}{|l|}{ Lead (blood) } \\
\hline <median $(48.7 \mu \mathrm{g} / \mathrm{l})$ & 82 & $6.5(2.2-19.0)$ & $10.0(6.6-14.5)$ \\
\hline$\geqslant$ median $(48.7 \mu \mathrm{g} / \mathrm{l})$ & 83 & $6.5(2.5-12.5)$ & $10.5(7.4-15.6)$ \\
\hline \multicolumn{4}{|l|}{ Cadmium (blood) } \\
\hline$<$ median $(0.6 \mu \mathrm{g} / \mathrm{l})$ & 80 & $6.6(2.2-13.4)$ & $9.7(6.6-13.4)$ \\
\hline$\geqslant$ median $(0.6 \mu \mathrm{g} / \mathrm{l})$ & 85 & $6.2(2.5-19.0)$ & $11.4(8.3-15.6)^{* * *}$ \\
\hline \multicolumn{4}{|l|}{ Mercury (blood) } \\
\hline <median $(2.0 \mu \mathrm{g} / \mathrm{l})$ & 79 & $6.0(2.5-19.0)$ & $10.6(6.6-15.6)$ \\
\hline$\geqslant$ median $(2.0 \mu \mathrm{g} / \mathrm{l})$ & 86 & $7.1(2.2-13.4)$ & $10.1(7.1-14.1)$ \\
\hline \multicolumn{4}{|l|}{ Urinary cadmium } \\
\hline <median $(0.37 \mu \mathrm{g} / \mathrm{g})$ & 83 & $6.9(2.2-14.9)$ & $9.8(7.1-14.1)$ \\
\hline$\geqslant$ median $(0.37 \mu \mathrm{g} / \mathrm{g})$ & 82 & $5.9(2.5-19.0)$ & $10.9(6.6-15.6)^{* * *}$ \\
\hline \multicolumn{4}{|l|}{ Urinary nickel } \\
\hline$<$ median $(0.77 \mu \mathrm{g} / \mathrm{g})$ & 83 & $6.4(2.5-14.9)$ & $10.2(7.1-15.6)$ \\
\hline$\geqslant$ median $(0.77 \mu \mathrm{g} / \mathrm{g})$ & 82 & $6.6(2.2-19.0)$ & $10.5(6.6-14.5)$ \\
\hline \multicolumn{4}{|l|}{ Urinary mercury } \\
\hline$<$ median $(0.66 \mu \mathrm{g} / \mathrm{g})$ & 83 & $6.5(2.2-19.0)$ & $10.3(6.6-15.6)$ \\
\hline$\geqslant$ median $(0.66 \mu \mathrm{g} / \mathrm{g})$ & 82 & $6.5(2.5-14.9)$ & $10.4(7.1-14.5)$ \\
\hline \multicolumn{4}{|l|}{ Urinary arsenic } \\
\hline$<$ median $(5.5 \mu \mathrm{g} / \mathrm{g})$ & 82 & $6.4(2.2-14.9)$ & $10.4(6.6-15.6)$ \\
\hline$\geqslant$ median $(5.5 \mu \mathrm{g} / \mathrm{g})$ & 83 & $6.7(3.0-19.0)$ & $10.4(7.1-14.1)$ \\
\hline
\end{tabular}

never consume fish have an average daily intake of arsenic of $0.94 \mu \mathrm{g} / \mathrm{kg}$ body weight. ${ }^{11}$ The German National Environmental Health Survey has found mean levels of arsenic in urine of subjects with regular fish consumption of $18 \mu \mathrm{g} / \mathrm{l}{ }^{12}$ The levels found in harbour workers under study were within this range.

As for arsenic the association between fish consumption and mercury concentrations in blood is well established. ${ }^{13-15}$
Only mercury concentrations in urine were weakly associated with amalgam fillings. This might be due to the fact that mercury levels in blood reflect inorganic and organic mercury compounds, while urinary mercury levels mainly indicate the inorganic portion of mercury. ${ }^{16}{ }^{17}$

The decrease in lead levels in blood over the course of the study are consistent with the decrease found in the general population. ${ }^{12}$ The well known associations between active

Table 5 Multiple regression analysis of micronuclei frequency and SCE rate as dependent variables and exposure, age, smoking status, fish consumption 5 days prior to the study, and exposure parameters as predictors

\begin{tabular}{|c|c|c|c|c|c|c|}
\hline & \multicolumn{3}{|c|}{ Micronuclei frequency } & \multicolumn{3}{|c|}{ SCE rate } \\
\hline & $\beta$ & SE of $\beta$ & $t$ & $\beta$ & SE of $\beta$ & $t$ \\
\hline & \multicolumn{3}{|c|}{$\left(n=165 ; R^{2} 0.11\right)$} & \multicolumn{3}{|c|}{$\left(n=152 ; R^{2} 0.31\right)$} \\
\hline Harbour workers $v$ controls & -0.59 & 0.43 & -1.38 & 0.20 & 0.24 & 0.82 \\
\hline Age (years) & 0.082 & 0.02 & $4.07^{* * *}$ & 0.014 & 0.012 & 1.21 \\
\hline Current smoker (yes $v$ no) & 0.27 & 0.44 & 0.62 & 1.24 & 0.32 & $3.89^{* * *}$ \\
\hline Fish consumption (yes $v$ no) & -0.15 & 0.43 & -0.35 & - & - & - \\
\hline Cadmium in blood ( $\mu \mathrm{g} / \mathrm{l})$ & - & - & - & 0.47 & 0.19 & $2.51^{*}$ \\
\hline Cadmium in urine ( $\mu \mathrm{g} / \mathrm{g}$ creatinine) & - & - & - & 0.15 & 0.32 & 0.46 \\
\hline Mercury in urine ( $\mu \mathrm{g} / \mathrm{g}$ creatinine) & 0.25 & 0.311 & 0.79 & - & - & - \\
\hline
\end{tabular}


smoking and cadmium levels in blood and urine were confirmed in our study. ${ }^{18} 19$

The cytogenetic markers were used to assess potential carcinogenic effects of the exposures under study. ${ }^{20-22}$ Occupational effects on cytogenetic markers have not been observed in our survey. Age was the only significant predictor of micronuclei frequency. This is in agreement with current literature. $^{23-27}$ As in other studies no association was seen between smoking and micronuclei frequency. ${ }^{23} 2527$

SCE rates were significantly associated with active smoking and cadmium levels in blood. The relation between smoking and SCE rate is well established. ${ }^{26}{ }^{28}$ Results on the association between cadmium levels in blood and SCE rate are conflicting. ${ }^{28}{ }^{29}$ Most studies that were not able to show such a correlation were limited by small numbers. ${ }^{29}{ }^{30}$ In vitro, a genotoxic effect of cadmium has been described. ${ }^{31} 32$ Using human lymphocytes this effect could not be confirmed. ${ }^{33}{ }^{34}$ In vivo, Fahmy and Aly ${ }^{35}$ found a dose dependent effect of cadmium chloride on SCE rate. The reason for this inconsistency might be that cadmium may serve as a marker of environmental tobacco smoke (ETS) exposure. ${ }^{18} 19$ Therefore, the association seen between cadmium and SCE rate may indicate the carcinogenic effect of passive smoke exposure. ${ }^{36}{ }^{37}$ Unfortunately, ETS exposure was not assessed in our study; therefore the association between ETS exposure and cadmium levels could not be tested.

In conclusion, we could not show an effect of long term occupational exposure to river silt aerosols on heavy metal concentrations in blood and urine of exposed workers. Additionally, no effects of occupational exposure on cytogenetic markers have been observed. Regular fish consumption might increase urinary arsenic concentrations well above current BEI levels. After adjustment for smoking habits, cadmium levels in blood were still a significant predictor of SCE rates. Therefore, cadmium levels in blood may reflect current exposure to ETS.

\section{ACKNOWLEDGEMENTS}

This study has been supported by "Amt für Strom- und Hafenbau, Hamburg". We thank the harbour workers and controls for participation. Our sincere thanks are extended to Etta Nern for the fieldwork, as well as to Susanne Finger, Marie-Helene Hein, Heike Laudehr, Kim Hue Tieu, and Susanne Stratmann for chemical analysis. Manfred Kaminski is gratefully acknowledged for rescuing the examination trailer from flood. We are indebted to Gisela Krause for data management.

\section{Authors' affiliations \\ R Wegner, K Radon, R Heinrich-Ramm, B Seemann, A Riess, F Koops, \\ B Poschadel, D Szadkowski, Ordinariat für Arbeitsmedizin der Universi-tät und Zentralinstitut für Arbeitsmedizin der Freien und Hansestadt Hamburg, Germany \\ Since this paper was submitted, Regine Heinrich-Ramm has sadly died}

\section{REFERENCES}

1 Hamer K, Karius V. Brick production with dredged harbour sediments. An industrial-scale experiment. Waste Manag 2002;22:521-30.

2 Wong CK, Yeung HY, Cheung RY, et al. Ecotoxicological assessment of persistent organic and heavy metal contamination in Hong Kong coastal sediment. Arch Environ Contam Toxicol 2000;38:486-93.

3 de Boer J, van der Zande TE, Pieters $\mathrm{H}$, et al. Organic contaminants and trace metals in flounder liver and sediment from the Amsterdam and Rotterdam harbours and off the Dutch coast. J Environ Monit 2001;3:386-93.

4 Angerer J, Schaller KH. Analytische Methoden zur Prüfung gesundheitsschädlicher Arbeitsstoffe; Analysen im biologischen Material. Weinheim: Verlag Chemie, 1996.

5 Fenech $M$. The cytokinesis-block micronucleus assay in nucleated cells. Prog Clin Biol Res 1990;340B:195-206.

6 Holz O, Scherer G, Brodtmeier S, et al. Determination of low level exposure to volatile aromatic hydrocarbons and genotoxic effects in workers at a styrene plant. Occup Environ Med 1995;52:420-8.
7 Wolff S, Perry P. Differential Giemsa staining of sister chromatids and the study of chromatid exchanges without autoradiography. Chromosoma 1974,48:341-53.

8 Jagdt B, Warncke $\mathrm{K}$, Auer $\mathrm{H}$, et al. Sleep deprivation does not induce sister chromatid exchange in humans. Mutat Res 1996;361:11-15.

9 Han B, Jeng WL, Chen RY, et al. Estimation of target hazard quotients and potential health risks for metals by consumption of seafood in Taiwan. Arch Environ Contam Toxicol 1998;35:711-20.

10 Mindt-Prüfert S, Heinrich-Ramm R, Szadkowski D. Zum alimentären Einflu $\beta$ auf die Arsenausscheidung im Harn bei arbeitsmedizinischen Vorsorgeuntersuchungen. Fulda: Rindt, 1999:S91-3

11 Becker K, Nöllke P, Hermann-Kunz E, et al. Zufuhr von Spurenelementen und Schadstoffen mit der Nahrung (Duplikate und Diet History) in den alten Bundesländern, Umweltbundesamt, 1996.

12 Krause C, Babisch W, Becker K, et al. Studienbeschreibung und Humanbiomonitoring, Deskription der Spurenelemente in Blut und Urin in der Bundesrepublik Deutschland, Institut für Wasser-, Boden- und Lufthygiene des Umweltbundesamtes, 1992.

13 Brune D, Nordberg GF, Vesterberg O, et al. A review of normal concentrations of mercury in human blood. Sci Total Environ $1991 ; 100: 235-82$.

14 Svensson BG, Schutz A, Nilsson A, et al. Fish as a source of exposure to mercury and selenium. Sci Total Environ 1992;126:61-74.

15 Harada M. Minamata disease: methylmercury poisoning in Japan caused by environmental pollution. Crit Rev Toxicol 1995;25:1-24.

16 Suzuki T, Hongo T, Abe T, et al. Urinary mercury level in Japanese school children: influence of dental amalgam fillings and fish eating habits. Sci Total Environ 1993;136:213-27.

17 Oskarsson A, Schultz A, Skerfving S, et al. Total and inorganic mercury in breast milk in relation to fish consumption and amalgam in lactating women. Arch Environ Health 1996:51:234-41.

18 Shaham J, Meltzer A, Ashkenazi R, et al. Biological monitoring of exposure to cadmium, a human carcinogen, as a result of active and passive smoking. J Occup Environ Med 1996;38:1220-8.

19 Hossn E, Mokhtar G, El Awady M, et al. Environmental exposure of the pediatric age groups in Cairo City and its suburbs to cadmium pollution. Sci Total Environ 2001;273:135-46.

20 Tucker JD, Preston RJ. Chromosome aberrations, micronuclei, aneuploidy, sister chromatid exchanges, and cancer risk assessment. Mutat Res 1996;365:147-59.

21 Murthy MK, Bhargava MK, Augustus M. Sister chromatid exchange studies in oral cancer patients. Indian J Cancer 1997;34:49-58.

22 Silva Augusto LG, Lieber SR, Ruiz MA, et al. Micronucleus monitoring to assess human occupational exposure to organochlorides. Environ Mol Mutagen 1997;29:46-52

23 Migliore L, Parrini M, Sbrana I, et al. Micronucleated lymphocytes in people occupationally exposed to potential environmental contaminants: the age effect. Mutat Res 1991;256:13-20.

24 Xue KX, Ma GJ, Wang S, et al. The in vivo micronucleus test in human capillary blood lymphocytes: methodological studies and effect of ageing. Mutat Res 1992;278:259-64.

25 Thierens H, Vral A, De Ridder L. A cytogenetic study of radiological workers: effect of age, smoking and radiation burden on the micronucleus frequency. Mutat Res 1996;360:75-82

26 Barale R, Chelotti L, Davini T, et al. Sister chromatid exchange and micronucleus frequency in human lymphocytes of 1,650 subjects in an Italian population: II. Contribution of sex, age, and lifestyle. Environ Mol Mutagen 1998;31:228-42.

27 Hessel H, Radon K, Pethran A, et al. The genotoxic risk of hospital, pharmacy and medical personnel occupationally exposed to cytostatic drugs-

28 Wulf HC, Kromann N, Kousgaard N, et al. Sister chromatid exchange (SCE) in Greenlandic Eskimos. Dose-response relationship between SCE and seal diet, smoking, and blood cadmium and mercury concentrations. Sci Total Environ 1986;48:81-94.

29 Nogawa K, Tsuritani I, Yamada Y, et al. Sister-chromatid exchanges in the lymphocytes of people exposed to environmental cadmium. Toxicol Lett 1986;32:283-8.

30 Tang XM, Chen XQ, Zhang JX, et al. Analysis of sister-chromatid exchange rate from peripheral lymphocyte of people exposed to environmental cadmium. Yi Chuan Xue Bao 1991;18:289-91.

31 Howard W, Leonard B, Moody W, et al. Induction of chromosome changes by metal compounds in cultured CHO cells. Toxicol Lett 1991;56:179-86.

32 Lin RH, Lee CH, Chen WK, et al. Studies on cytotoxic and genotoxic effects of cadmium nitrate and lead nitrate in Chinese hamster ovary cells. Environ Mol Mutagen 1994;23:143-9.

33 Bassendowska-Karska E, Zawadzka-Kos M. Cadmium sulfate does not induce sister chromatid exchanges in human lymphocytes in vitro. Toxicol Lett 1987;37:173-5

34 Hartmann A, Speit G. Comparative investigations of the genotoxic effects of metals in the single cells gel (SCG) assay and the sister chromatid exchange (SCE) test. Environ Mol Mutagen 1994;23:299-305.

35 Fahmy MA, Aly FA. In vivo and in vitro studies on the genotoxicity of cadmium chloride in mice. J Appl Toxicol 2000;20:231-8.

36 Boffetta P. Involuntary smoking and lung cancer. Scand J Work Environ Health 2002;28(suppl 2):30-40.

37 Phillips DH. Smoking-related DNA and protein adducts in human tissues. Carcinogenesis 2002;23:1979-2004. 